BIODIK: Jurnal IImiah Pendidikan Biologi
ISSN 2580-0922 (online), ISSN 2460-2612 (print)
Volume 7, Nomor 02, Tahun 2021, Hal. 131-142
Available online at:
https://online-journal.unja.ac.id/biodik

Research Article

open 2 access

\title{
Efektivitas Augmented Reality Terhadap Higher Order Thinking Skills Siswa Pada Pembelajaran Biologi
}

\section{(The Effectiveness of Augmented Reality Towards Students' Higher Order Thinking Skills in Biology Subject)}

Fitri Sylvia*, Billyardi Ramdhan, Sistiana Windyariani

Program Studi Pendidikan Biologi, Universitas Muhammadiyah Sukabumi

JI. R. Syamsudin, S.H. No. 50, Cikole, Kec. Cikole, Kota Sukabumi, Jawa Barat 43113

Corresponding Autors : fitrisylvia009@ummi.ac.id

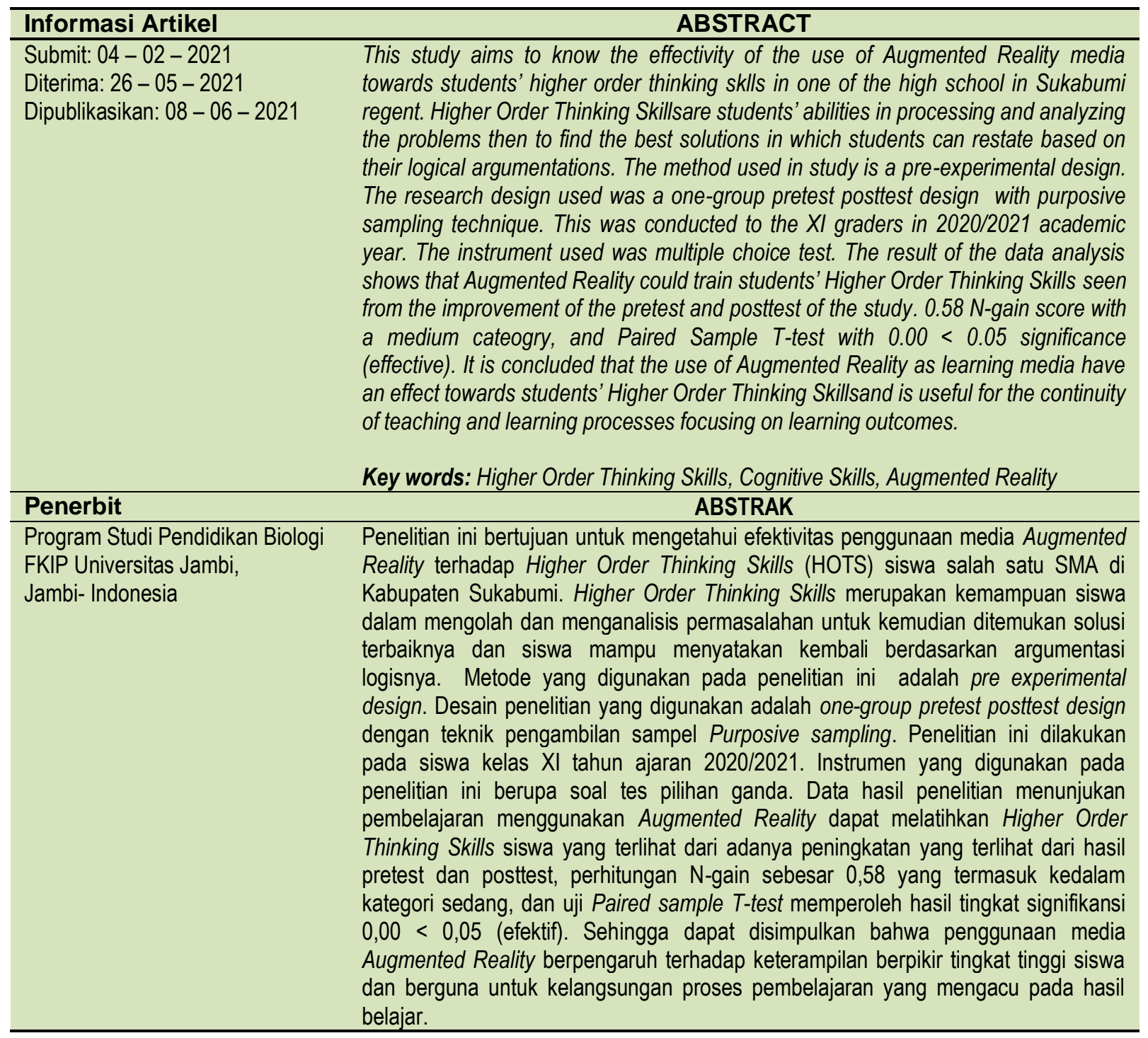


Kata kunci: Higher Order Thinking Skills, Keterampilan Kognitif, Augmented Reality

\section{(i) (2) (2) \\ BY NC SA}

This BIODIK : Jurnal IImiah Pendidikan Biologi is licensed under a CC BY-NC-SA (Creative Commons Attribution-ShareAlike 4.0 International License)

\section{PENDAHULUAN}

Higher Order Thinking Skills (HOTS) sangat erat kaitannya dengan sistem pendidikan di Indonesia. Dengan diterapkannya kurikulum 2013 di sekolah pemerintah mengharapkan para siswa dapat mencapai berbagai kompetensi dengan penerapan Higher Order Thinking Skills (Sani, 2019) . Kompetensi tersebut diantaranya berpikir kritis, kreatif dan inovatif, kemampuan bekerja sama dan kepercayaan diri (Ariyana et al., 2018). Lima hal yang disampaikan pemerintah seiring dengan apa yang bisa dihasilkan oleh HOTS. Oleh karena itu, dalam materi pembelajaran dan evaluasi-evaluasi terdapat beberapa soal dengan level HOTS. Higher Order Thinking Skills juga digunakan mengingat masih sangat rendahnya peringkat PISA (Programme for International Student Assessment). Berdasarkan data hasil penelitian PISA skor Indonesia mengalami kemerosotan selama empat tahun terakhir, posisi Indonesia menurun di seluruh bidang yang diujikan : membaca, matematika dan sains. Indonesia berada paling bawah bersama Filipina jika dibandingkan dengan negara-negara di Asia Tenggara lainnya. Berdasarkan hasil dari PISA pada bulan Desember 2018 skor Indonesia berada diperingkat 70 dari 78 negara pada kategori sains (Kemendikbud, 2019). Tingkat skor tersebut menurun dari tes PISA pada tahun 2015 lalu dimana Indonesia berada pada peringkat 64 . Penurunan hasil PISA yang terjadi pada tahun 2018 ini menunjukan bahwa performa akademis siswa-siswi di Indonesia masih perlu banyak dilatih dan dikembangkan lagi.

Pembentukan pola pikir yang lebih tinggi diharapkan dapat dimiliki siswa guna tercapainya tujuan dalam pembelajaran. Kemampuan berpikir tingkat tinggi atau Higher Order Thinking Skills memiliki peranan yang sangat penting di dalam pembelajaran. Pada saat proses pembelajaran, siswa dituntut tidak hanya pandai dalam mendengar, melainkan mampu memahami informasi dan mampu menyerap arti dari materi yang berguna untuk kelangsungan proses pembelajaran yang mengacu pada hasil belajar. Kemampuan berpikir tingkat tinggi ini dapat diterapkan siswa dengan memberikan pengalaman secara langsung yang diawali dengan pengamatan untuk kemudian dirumuskan dalam bentuk ungkapan dan diproses dengan persepsi atau penalaran kemampuan masing-masing siswa. Kemampuan berpikir tingkat tinggi ini akan melatih siswa dalam mengolah dan menganalisis permasalahan untuk kemudian ditemukan solusi terbaiknya dan siswa mampu menyatakan kembali berdasarkan argumentasi logisnya. Faktanya, sampai saat ini masih banyak siswa yang belum mampu memahami konsep materi pada saat proses pembelajaran, siswa belum mampu menjelaskan kembali materi yang dijelaskan oleh guru. Ketidakmampuan siswa dalam menyatakan kembali materi dikarenakan siswa kurang memahami akan konsep materi yang dijelaskan oleh guru.

Seperti halnya kondisi di salah satu SMA di Kabupaten Sukabumi. Berdasarkan hasil dari wawancara dengan salah seorang guru biologi di SMA tersebut, ia menyatakan bahwa sebagian besar siswa belum memiliki keterampilan berpikir tingkat tinggi. Hal ini didapatkan dari beberapa nilai hasil ujian siswa dalam kategori soal-soal HOTS nilai yang didapat siswa masih dalam kategori rendah. 
Rendahnya nilai yang didapat siswa disebabkan karena guru yang belum melatih keterampilan berpikir tingkat tinggi didalam pembelajaran yang menyebabkan kurangnya pemahaman siswa dalam memahami materi yang diberikan. Penyampaian materi konsep yang hanya diberikan melalui gambar atau tulisan membuat siswa kesulitan dalam memahami materi. Untuk itu, penggunaan strategi dalam pembelajaran dengan memanfaatkan media sebagai sarana sangat penting digunakan.

Kemampuan dalam mengolah dan menganalasis informasi dapat dengan mudah tersalurkan apabila menggunakan media sebagai unsur dalam pembelajaran. Seperti yang dikemukakan oleh (Prasetya Adi, 2018) pemecahan masalah menggunakan pemanfaatan media dengan mengintegrasikan Teknologi Informasi dan Komunikasi (TIK) dalam pembelajaran dirasa tepat untuk meningkatkan Higher Order Thinking Skills siswa dalam proses pembelajaran. Perkembangan penggunaan teknologi saat ini yang lekat dengan kehidupan sehari-hari dapat mempengaruhi sistem pembelajaran di abad 21. Pada pembelajaran abad 21 guru ditantang untuk mampu menghasilkan siswa yang dapat turut berperan dalam tatanan kehidupan di abad ini (Windyariani, 2019).Salah satu keterampilan literasi yang dibutuhkan siswa untuk menghadapi tantangan abad 21 adalah: technology and digital literacy skills, yaitu kemampuan siswa dalam menggunakan, memanfaatkan, mengevaluasi dan mengembangkan teknologi serta digital content untuk memecahkan masalah berkaitan dengan pembelajarannya.

Salah satu teknologi yang dapat mendukung sistem pembelajaran di abad 21 adalah teknologi realitas maya yang biasa disebut dengan Virtual Reality (VR) . Virtual Reality menampilkan informasi mengenai dunia virtual yang dapat ditampilkan secara real kepada pengguna baik secara visual maupun audio. Perkembangan teknologi saat ini menghasilkan cabang baru dalam Virtual Reality yang disebut Augmented Reality (AR). Prinsipnya secara umum menurut (Hartanto, 2016), yaitu bersifat interaktif dalam menggabungkan dunia virtual secara nyata, immersion (membenamkan/memasukan objek ke dalam dunia nyata), real time, dan objek visual biasanya berbentuk 3 dimensi. Aplikasi yang mendukung penggunaan media Augmented Reality untuk menunjang pembelajaran keterampilan berpikir tingkat tinggi yaitu Assemblr Edu. Aplikasi ini menurut (Ryza, 2017) memiliki kelebihan dapat memberikan pengalaman langsung kepada siswa, dapat menunjukan objek secara keseluruhan dan dapat memberikan gambaran struktur organisasi secara jelas. CEO Assemblr Edu ini menyatakan bahwa aplikasi ini didesain untuk membantu para pengguna baik guru maupun siswa dalam menggunakan dan membuat konten 3D yang divisualisasikan ke dalam bentuk Augmented Reality. Adapun gambaran dari aplikasi Assemblr Edu dapat dilihat pada Gambar 1. 


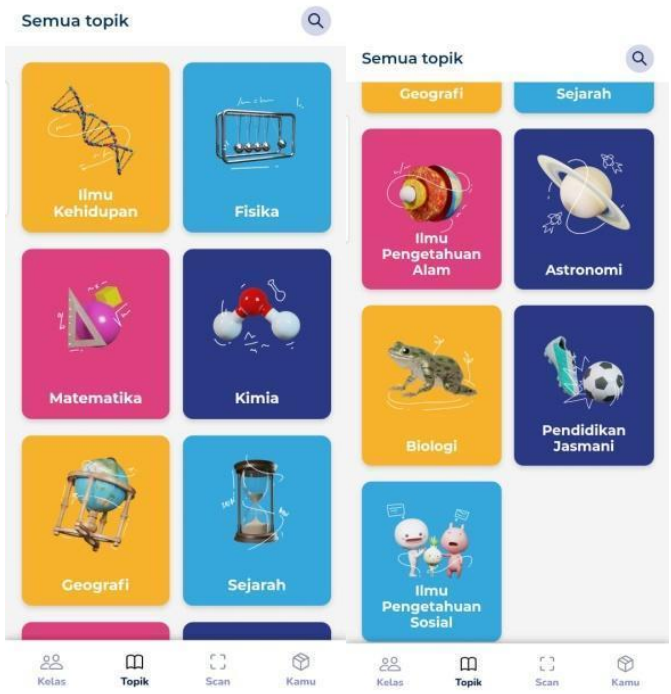

Gambar 1. Aplikasi Assemblr Edu

Untuk melatihkan Higher Order Thinking Skills (HOTS) siswa, selain siswa harus memiliki kemampuan dalam mengolah dan manganalisis informasi, penggunaan media juga sangat diperlukan. Oleh karena itu, penelitian ini penting dilakukan oleh peneliti untuk menganalisis Higher Order Thinking Skillssiswa dengan bantuan media Augmented Reality. Penggunaan media Augmented Reality ini sebagai solusi dalam proses pembelajaran agar lebih interaktif dan menarik sehingga dapat meningkatkan keterampilan berpikir tingkat tinggi siswa dan berguna untuk kelangsungan proses pembelajaran yang mengacu pada hasil belajar.

\section{METODE PENELITIAN}

Metode yang digunakan pada penelitian adalah pre experimental design. Desain penelitian yang digunakan adalah one-group pretest posttest design, yaitu pengambilan satu kelompok atau kelas yang diberikan pra dan pasca uji. Rancangan one-group pretest posttest design ini dilakukan hanya pada satu kelompok tanpa adanya kelompok pembanding (Sugiyono, 2015). Populasi yang digunakan pada penelitian ini yaitu siswa kelas XI pada salah satu SMA di Kabupaten Sukabumi pada tahun ajaran 2020/2021. Sedangkan sampel yang digunakan sebanyak 30 siswa yang diperoleh dengan teknik purposive sampling yaitu pengambilan sampel yang didasarkan pada pertimbangan tertentu (Sugiyono, 2015). Penelitian ini dilakukan pada bulan April 2021. Pengambilan data menggunakan instrumen tes soal pilihan ganda sebanyak 10 soal yang disesuaikan dengan 3 indikator HOTS menurut(Anderson \& Krathwohl, 2001), meliputi : 1) Menganalisis, 2) Mengevaluasi dan 3) Mencipta. Soal tersebut telah melalui tahap uji reliabilitas dengan nilai sebesar 0,74 , simpangan baku sebesar 3,86 dan korelasi XY sebesar 0,59 . 

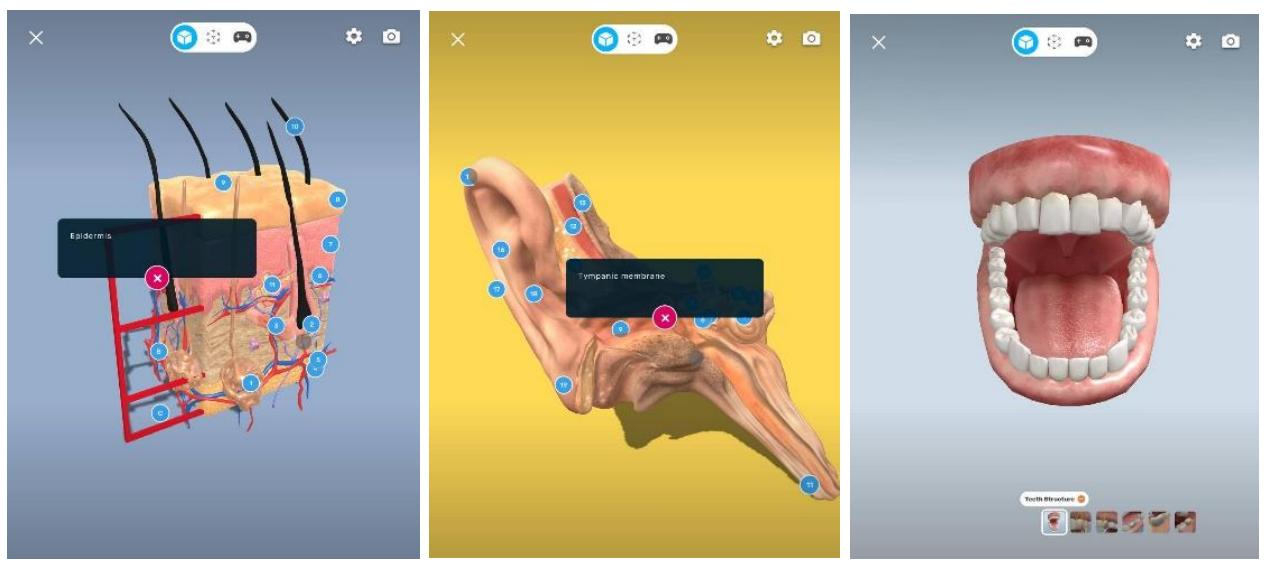

Gambar 2. Gambaran Materi Alat Indera pada Manusia

(Sumber : Assemblr Edu)

Tahap pembelajaran materi yang disampaikan menggunakan media Augmented Reality berbantuan Aplikasi Assemblr Edu seperti yang tertera pada gambar 2. Teknik pengumpulan data dilakukan secara digital, dimana peserta didik melaksanakan pembelajaran dari rumah (daring) berbantuan aplikasi video conference Google meet dan mengisi tes soal menggunakan Google form. Soal-soal yang dipakai disesuaikan dengan Peraturan Menteri Pendidikan dan Kebudayaan (PERMENDIKBUD) 2016 yang mengacu pada Kompetensi Dasar 3.10. Menganalisis hubungan antara struktur jaringan penyusun organ pada sistem koordinasi (saraf, hormon, dan alat indera) dalam kaitannya dengan mekanisme koordinasi dan regulasi serta gangguan fungsi yang mungkin terjadi pada sistem koordinasi manusia. Dengan Indikator Pencapaian Kompetensi seperti tertera pada Tabel 1.

Tabel 1. Indikator Pembelajaran pada Materi Sistem Koordinasi

\begin{tabular}{ll}
\hline No & \multicolumn{1}{c}{ Indikator Pembelajaran } \\
\hline 1. & Menganalisis mekanisme kerja alat indera pada manusia \\
\hline 2. & Mengaitkan hubungan pola hidup dengan respon terhadap alat indera. \\
\hline 3. & Menafsirkan mekanisme kerja alat indera pada manusia \\
\hline 4 & Menyimpulkan percobaan sederhana mengenai mekanisme kerja alat indera pada manusia \\
\hline 5. & Merancang percobaan sederhana mengenai mekanisme kerja alat indera pada manusia \\
\hline
\end{tabular}

Kisi-kisi soal higher order thinking skils meliputi kemampuan menganalisis, kemampuan mengevaluasi dan kemampuan mencipta dapat dilihat pada table 2 .

Tabel 2. Kisi-kisi soal Higher Order Thinking Skills

\begin{tabular}{llc}
\hline No & Indikator HOTS & No Pertanyaan \\
\hline 1. & Kemampuan Menganalisis & $1,4,5,6,9$ \\
\hline 2. & Kemampuan Mengevaluasi & $2,3,7$ \\
\hline 3. & Kemampuan Mencipta & 8,10 \\
\hline & Jumlah Soal & 10 \\
\hline
\end{tabular}

(Sumber : Anderson dan Krathwohl, 2001) 


\section{HASIL PENELITIAN DAN PEMBAHASAN}

Higher Order Thinking Skills adalah kemampuan siswa dalam mengolah informasi, menganalisis, dan mentransformasikan pengetahuan yang dimilikinya. (Ariyana et al., 2018) mengemukakan bahwa Higher Order Thinking Skills adalah proses dimana siswa dapat berpikir secara kompleks dalam menguraikan materi, menyimpulkan, menganalisis, merepresentasi dan dapat membangun kolerasi dengan melibatkan aktivitas mental yang paling dasar. Seperti yang dikemukakan oleh (Sari, 2019), Higher Order Thinking Skills dapat dikembangkan melalui proses pembelajaran yang dapat melatihkan siswa untuk menganalisis penalarannya melalui proses menjawab soal yang berorientasi pada kemampuan berpikir tingkat tinggi. Pada saat dihadapkan dengan soal-soal yang berorientasi pada kemampuan berpikir tingkat tinggi, siswa dapat mengembangkan kemampuannya dalam mengolah dan menganalisis informasi. Soal-soal yang berorientasi pada kemampuan berpikir tingkat tinggi umumnya bersifat soal soal yang berorientasi pada masalah baik berupa gambar, grafik, tabel maupun teks.

Berdasarkan hasil penelitian, ditemukan bahwa setelah dilakukannya pembelajaran menggunakan media Augmented Reality berbantuan aplikasi Assemblr Edu yang diukur menggunakan instrumen tes soal yang dibuat berdasarkan indikator HOTS menurut (Anderson \& Krathwohl, 2001) diperoleh hasil yang disajikan dalam bentuk grafik seperti yang tertera pada gambar 3 .

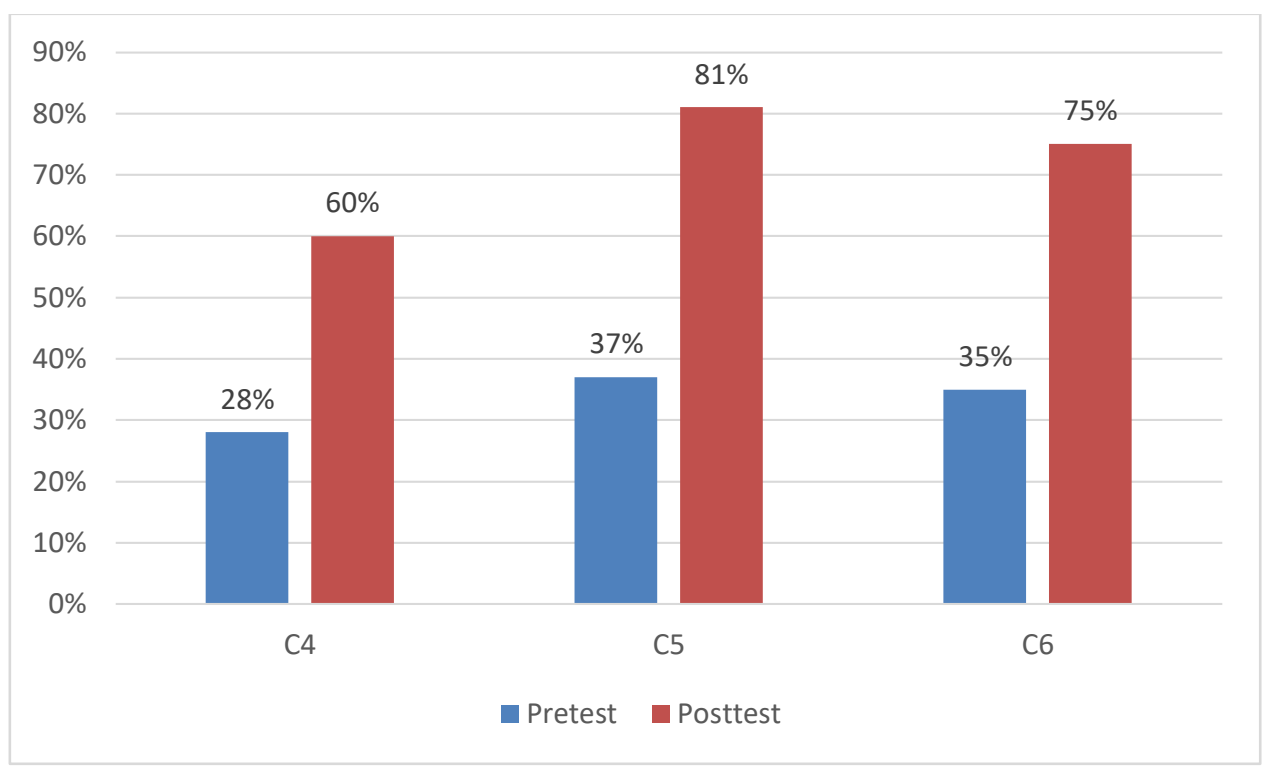

Gambar 3. Perolehan Skor Berdasarkan Indikator HOTS

Berdasarkan hasil yang tertera pada gambar 3, menunjukan adanya perbedaan yang signifikan pada skor pretest dan posttest. Perbedaan yang signifikan juga terlihat dari hasil rata-rata $\mathrm{N}$-gain dari pretest dan posttest sebesar 0,71. Hal ini menunjukan bahwa efektifitas penggunaan media Augmented Reality yang digunakan termasuk kedalam kategori tinggi. Hasil uji $\mathrm{N}$-gain dapat dilihat pada tabel 4.

Tabel 4. Kriteria N-gain nilai pretest dan posttest

\begin{tabular}{ccc}
\hline Data & Rata-rata Ngain & Kategori \\
\hline $\begin{array}{c}\text { Nilai Pretest dan } \\
\text { Posttest }\end{array}$ & 0,58 & Sedang \\
\hline
\end{tabular}

Selanjutnya dilakukan uji normalitas. Data yang digunakan dalam uji normalitas ini adalah ratarata nilai pretest dan posttest. Hasil uji normalitas dapat dilihat pada tabel 5. 
Tabel 5. Uji Normalitas Shapiro wilk

Tests of Normality

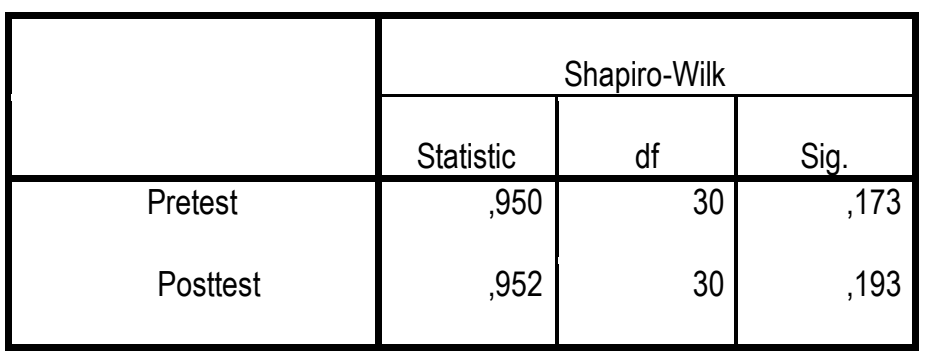

a. Lilliefors Significance Correction

Berdasarkan uji normalitas dengan uji shapiro wilk, diperoleh nilai Asymp Sig. Untuk nilai pretest dan posttest lebih besar dari a $(0,05)$ sehingga diketahui bahwa data yang digunakan berdistribusi normal. Selanjutnya dilakukan uji homogenitas untuk mengetahui apakah data yang digunakan homogen atau tidak. Hasil uji homogenitas dapat dilihat pada tabel 6.

Tabel 6. Uji Homogenitas

Test of Homogeneity of Variances

\begin{tabular}{|c|c|c|c|}
\hline Levene Statistic & $\mathrm{df1}$ & $\mathrm{df} 2$ & Sig. \\
\hline 2,045 & 4 & 24 & 120 \\
\hline
\end{tabular}

Berdasarkan hasil uji homogenitas dengan Levene test diperoleh bahwa nilai signifikansi sebesar 0,120 yang artinya lebih besar dari a $(0,05)$ sehingga dapat diketahui bahwa data yang digunakan homogen. Seperti yang telah diketahui bahwa data yang digunakan berdistribusi ormal dan homogen, maka selanjutnya dilakukan uji hipotesis menggunakan rumus uji Paired-Sample Test. Hasil uji homogenitas dapat dilihat pada tabel 7.

Tabel 7 . Uji Hipotesis dengan Paired-Sample Test

Paired Samples Test

\begin{tabular}{|c|c|c|c|c|c|c|c|c|}
\hline & \multicolumn{5}{|c|}{ Paired Differences } & \multirow{3}{*}{$\mathrm{t}$} & \multirow{3}{*}{$d f$} & \multirow{3}{*}{ Sig. (2-tailed) } \\
\hline & \multirow[t]{2}{*}{ Mean } & \multirow[t]{2}{*}{$\begin{array}{c}\text { Std. } \\
\text { Deviation }\end{array}$} & \multirow{2}{*}{$\begin{array}{l}\text { Std. } \\
\text { Error } \\
\text { Mean }\end{array}$} & \multicolumn{2}{|c|}{$\begin{array}{l}95 \% \text { Confidence } \\
\text { Interval of the } \\
\text { Difference }\end{array}$} & & & \\
\hline & & & & Lower & Upper & & & \\
\hline $\begin{array}{ll}\text { Pair } & \text { Pre - } \\
1 & \text { Post }\end{array}$ & $-43,667$ & 14,499 & 2,647 & $-49,081$ & $-38,253$ & $-16,495$ & 29 &, 000 \\
\hline
\end{tabular}

Berdasarkan hasil uji hipotesis dengan Paired-Sample Test, maka didapat nilai Sig (Asymp. Sig 2-tailed) sebesar 0,000 dimana nilai ini menunjukan nilai yang lebih kecil dari batas kritis penelitian yaitu 0,05 . Sehingga diketahui adanya perbedaan yang signifikan antara nilai pretest dan posttest. Dan dapat disimpulkan bahwa media Augmented Reality teruji keefektifannya dalam melatihkan Higher Order Thinking Skills siswa dalam pembelajaran. 
Hasil penelitian menunjukan bahwa terdapat perbedaan yang signifikan antara nilai pretest dan posttest. Siswa memiliki nilai yang lebih tinggi pada saat posttest dibandingkan dengan nilai pretest. Hal ini memungkikan karena pada saat proses pembelajaran berlangsung siswa mendapatkan pelajaran dengan menggunakan media Augmented Reality. Siswa mendapatkan materi berupa gambar 3D yang dapat divisualisasikan ke dalam dunia nyata dan siswa sendiri yang dapat mengoperasikannya secara langsung melalui smartphone miliknya sehingga dapat memudahkan siswa dalam memahami materi pelajaran yang di sampaikan. Penggunaan media pembelajaran sangat berperan dalam peningkatan hasil belajar dan dapat membangun komunikasi yang interaktif antara guru dan siswa (Arifin et al., 2016). Sementara nilai pretest yang didapatkan siswa merupakan nilai yang didapat sebelum pembelajaran dilakukan. Nilai pretest ini menunjukan pengetahuan awal yang dimiliki siswa mengenai materi sistem koordinasi pada pokok bahasan alat indera pada manusia.

Melihat grafik yang tertera pada gambar 3, perolehan nilai posttest pada tingkatan soal C4 (menganalisis) terjadi peningkatan dengan nilai persentase $60 \%$ yang termasuk ke dalam kategori cukup, pada tingkatan soal C5 (mengevaluasi) terjadi peningkatan dengan nilai persentase $81 \%$ yang termasuk ke dalam kategori sangat baik, dan pada tingkatan soal C6 (mencipta) terjadi peningkatan dengan nilai persentase $75 \%$ yang termasuk ke dalam kategori baik. Tingkatan soal C4 (Menganalisis) dapat melatihkan siswa dalam memecah materi kedalam bagian-bagian dan menentukan bagaimana bagian-bagian itu terhubung ke struktur atau tujuan keseluruhan. Tingkatan soal C5 (Mengevaluasi) melatihkan siswa dalam membuat pertimbangan berdasarkan kriteria atau standar. Dan tingkatan soal C6 (Mencipta) melatihkan siswa dalam menempatkan unsur-unsur secara bersama-sama untuk membentuk keseluruhan secara fungsional dan menyusun kembali unsur-unsur ke dalam pola atau struktur baru (Ariyana et al., 2018).

Tingkatan soal yang dibuat pun disesuaikan dengan dimensi pengetahuan menurut (Anderson \& Krathwohl, 2001) yang meliputi : Pengetahuan Faktual, Konseptual, Prosedural dan Metakognitif. Pengetahuan faktual berisi elemen-elemen yang diketahui siswa untuk memecahkan masalah dalam pembelajaran. Pengetahuan konseptual berisi teori-teori eksplisit dan implisit dalam pembelajaran. Pengetahuan prosedural berisi rangkaian langkah-langkah, metode-metode atau teknik-teknik tertentu di dalam pembelajaran. Pengetahuan metakognitif merupakan pengetahuan mengenai kesadaran siswa untuk lebih sadar dan bertanggung jawab dalam pengetahuan dan pemikiran mereka sendiri. Kesadaran siswa akan membuat mereka cenderung belajar lebih baik (Ariyana et al., 2018).

Dari hasil analisis menggunakan instrumen soal HOTS yang merujuk pada indikator menurut (Anderson \& Krathwohl, 2001) dapat mempengaruhi kemampuan berpikir tingkat tinggi siswa. Level kognitif C4-C6 yang digunakan menuntut siswa untuk berpikir pada level yang lebih tinggi. Dimana siswa harus mampu berpikir dengan melibatkan aktivitas mental dalam usaha mengeksplorasi pembelajaran yang lebih kompleks untuk mencapai suatu tujuan yaitu memperoleh pengetahuan yang meliputi berpikir analitis, evaluatif dan sintesis (Sari, 2019). Hasil pembelajaran menggunakan media Augmented Reality, diperoleh peningkatan hasil belajar siswa dalam ranah kemampuan berpikir tingkat tinggi. Hal ini terlihat dari adanya peningkatan pada tiap indikator HOTS baik pada kemampuan menganalisis, kemampuan mengevaluasi dan mencipta.

Adapun adanya peningkatan yang cukup tinggi yang ditunjukan pada ranah C5 (mengevaluasi) dan C6 (mencipta) menunjukan bahwa pada saat proses pembelajaran dengan menggunakan media

\section{Sylvia, $d k k$}


Augmented Reality lebih melatihkan kemampuan siswa dalam mengevaluasi dan mencipta. Hal ini terlihat dalam proses pembelajaran dimana peneliti menggunakan model pembelajaran Problem Based Learning (PBL) yang mengaitkan masalah kehidupan sehari-hari dengan pembelajaran. Mengaitkan masalah yang umum di jumpai siswa dapat membuat siswa lebih mengeksplorasi materi dan mengasah keterampilan berfikirnya serta kemampuan pemecahan masalahnya. (Shofiyah \& Wulandari, 2018) menyatakan bahwa Problem Based Learning (PBL) dapat melatihkan siswa melakukan penyelidikan dengan menganalisis informasi, melakukan eksperimen dan membuat kesimpulan atas penyelidikan. Sejalan dengan yang dikemukakan oleh (Shofiyah \& Wulandari, 2018), (Ariyana et al., 2018) menyatakan bahwa model Problem Based Learning (PBL) menuntut siswa untuk dapat menggunakan kemampuan berpikir tingkat tinggi, terutama kemampuan pemecahan masalah dan penyelesaian dari permasalahan yang ditemukan.

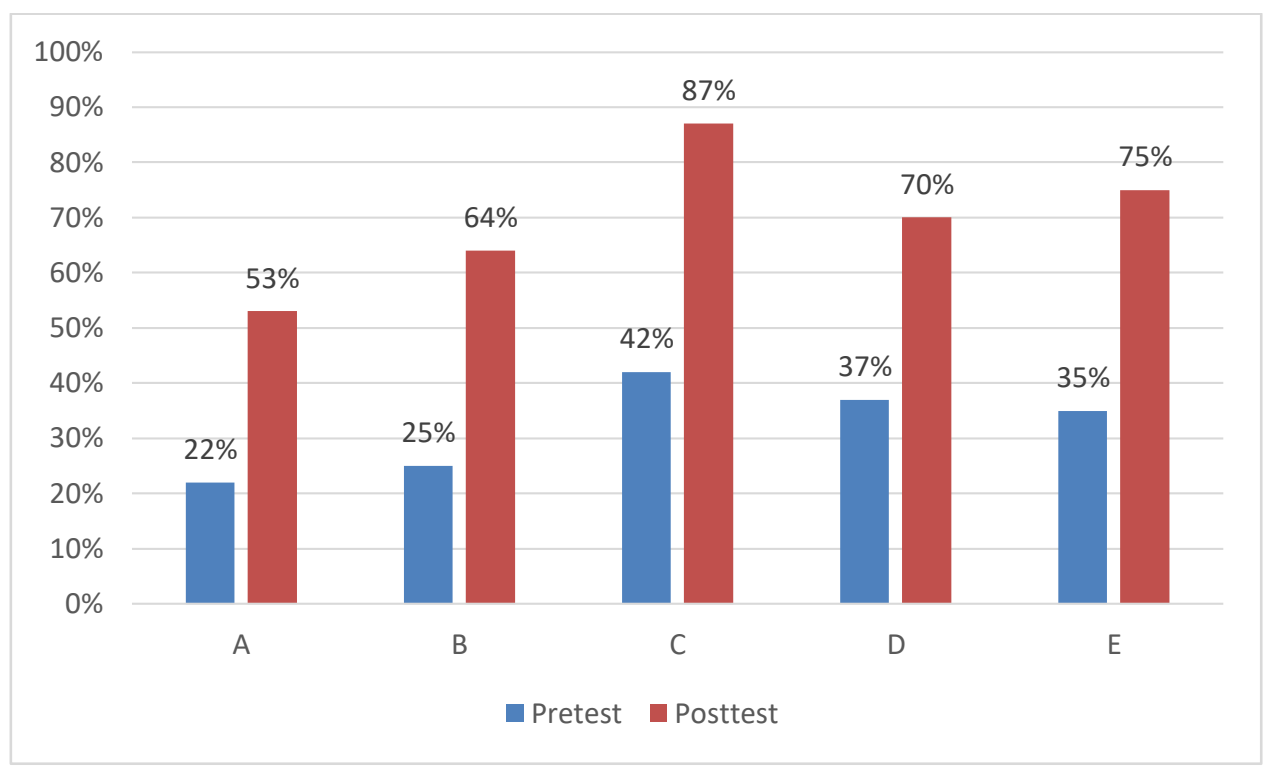

Gambar 4. Perolehan Skor Berdasarkan Indikator Pembelajaran

Sementara, Jika dilihat melalui aspek perolehan skor berdasarkan indikator pembelajaran menunjukan bahwa hasil posttest lebih tinggi dibandingkan hasil pretest dengan hasil yang cukup signifikan. Indikator C yaitu "menafsirkan mekanisme kerja alat indera pada manusia" memiliki perolehan skor yang lebih tinggi dibandingkan dengan indikator yang lainnya. Skor yang didapat dan kemampuan dalam menjawab soal dari setiap indikator pun sangat beragam, hal tersebut dapat terjadi karena kemampuan akademis yang dimiliki siswa sangat beragam. Dalam penelitian ini, penggunaan media pembelajaran Augmented Reality berbantuan aplikasi Assemblr Edu sangat berpengaruh terhadap peningkatan hasil belajar siswa dalam ranah kognitif. Jika dibandingkan dengan nilai yang diperoleh siswa sebelumnya masih dalam kategori rendah, maka dengan diterapkannya media pembelajaran Augmented Reality berbantuan aplikasi Assemblr Edu ini menunjukan adanya kenaikan nilai yang diperoleh siswa menjadi dalam kategori baik dan sangat baik.

Pada indikator A yaitu "Menganalisis mekanisme kerja alat indera pada manusia" memperoleh hasil yang paling rendah jika dibandingkan dengan nilai posttest pada indikator lainnya. Namun, terjadi peningkatan jika dilihat berdasarkan nilai pretest siswa sebelumnya. Indikator A berisi soal dalam bentuk cerita sehingga melatih siswa untuk memiliki kemampuan literasi membaca. Kemampuan siswa 
dalam membaca teks secara teliti akan mempermudah siswa dalam menjawab soal tersebut sehingga dapat diketahui kemampuan siswa dalam menganalisis soal. Pada indikator B yaitu "Mengaitkan hubungan pola hidup dengan respon terhadap alat indera" juga terjadi peningkatan pada nilai posttest dibandingkan dengan pretest. Terlihat siswa sudah bisa menghubungkan hasil pemikirannya dengan kehidupan sehari-hari. Pada indikator $\mathrm{C}$ yaitu "Menafsirkan mekanisme kerja alat indera pada manusia" memperoleh hasil yang paling tinggi jika dibandingkan dengan nilai posttest pada indikator lainnya. Penggunaan media Augmented Reality pada pembelajaran ini sangat berpengaruh dalam membentuk kemampuan $\mathrm{C} 5$ (mengevaluasi) siswa. Indikator $\mathrm{C}$ yang berisi soal dalam bentuk gambar memudahkan siswa untuk menjawab soal tersebut. Pada aplikasi Assemblr Edu yang digunakan siswa dalam proses pembelajaran pun tersedia dalam bentuk gambar 3D sehingga lebih memudahkan siswa dalam memahami materi yang disampaikan. Pada indikator D yaitu "Menyimpulkan percobaan sederhana mengenai mekanisme kerja alat indera pada manusia" juga terjadi peningkatan pada nilai posttest. Setelah pembelajaran dilakukan, terlihat bahwa siswa sudah bisa memecahkan masalah dengan cara penyelesaian dalam bentuk simpulan. Sementara pada indikator E yaitu "Merancang percobaan sederhana mengenai mekanisme kerja alat indera pada manusia" juga terjadi peningkatan yang cukup signifikan pada nilai posttest. Pembelajaran menggunakan media Augmented Reality ini terlihat berpengaruh dalam membentuk kemampuan C6 (mencipta) siswa. Melalui media yang terintegrasi dalam bentuk gambar 3D ini dapat membangun pola pemikiran siswa untuk dapat menyusun atau membentuk pola atau struktur yang baru.

Pada penelitian ini, penggunaan media Augmented Reality memiliki pengaruh yang baik terhadap peningkatan hasil belajar siswa. Terlebih dengan penggunaan aplikasi Assemblr Edu yang menampilkan gambar 3D sehingga memberikan gambaran struktur organisasi secara jelas. Seperti yang dikemukakan oleh (Hutchison, 2018), penggunaan media virtual dapat membuat siswa mempelajari sains dari perspektif yang berbeda serta dapat meningkatkan literasi digital. Penggunaan aplikasi ini dapat membuat siswa lebih memahami materi pembelajaran yang diberikan, karena materi yang bersifat abstrak akan lebih mudah dipahami dengan visualisasi 3D yang dimiliki oleh aplikasi Assemblr Edu (Wulandari, 2020). Desain aplikasi Augmented Reality juga dapat memicu minat belajar siswa untuk mempelajari lebih lanjut tentang materi pelajaran (Kouzi, 2019). Selain itu, penggunaan media pembelajaran Augmented Reality berbantuan aplikasi Assemblr Edu yang dapat diunduh oleh siswa menggunakan smartphone miliknya dan dapat dioperasikan oleh siswa sendiri juga dapat membuat siswa berperan aktif dalam pembelajaran sehingga Higher Order Thinking Skillsdapat dilatihkan dengan memberikan pengalaman secara langsung yang diawali dengan pengamatan oleh siswa itu sendiri.

Untuk itu, diketahui bahwa penggunaan media Augmented Reality sangat tepat diterapkan sebagai media pembelajaran dengan dikombinasikan dengan model pembelajaran Problem Based Learning (PBL) untuk meningkatkan Higher Order Thinking Skills siswa. Penggunaan aplikasi Assemblr Edu sebagai bagian dari Augmented Reality dapat memberikan pengalaman secara langsung kepada siswa sehingga memudahkan siswa dalam memahami materi pelajaran. Media Augmented Reality ini juga bisa menjadi solusi bagi para guru untuk dapat melatihkan kemampuan berpikir tingkat tinggi siswa di dalam kelas. Peneliti merekomendasikan media Augmented Reality ini karena sesuai penelitian yang dilakukan oleh (Wulandari, 2020) menyatakan bahwa penggunaan media Augmented Reality dapat memfasilitasi penguasaan konsep dan berpikir kreatif siswa. (Ozdamli \& Karagozlu, 2018) yang 
menyatakan bahwa Penggunaan Augmented Reality dapat meningkatkan fokus dan ketertarikan siswa dalam pembelajaran. Selanjutnya, (Fuchova \& Korenova, 2019) yang menyatakan bahwa pemahaman siswa setelah menggunakan Augmented Reality didalam pembelajaran menjadi lebih dalam, motivasi menjadi lebih besar dan kreativitasnya sangat terdorong. Kemudian, (Nuanmeesri, 2018) menyatakan bahwa penggunaan media Augmented Reality dalam pembelajaran dapat meningkatkan hasil belajar yang lebih baik. Penggunaan media Augmented Reality dapat berkontribusi dalam pembelajaran yang efektif dan hasil yang lebih baik dalam pemahaman.

\section{SIMPULAN}

Berdasarkan hasil penelitian yang telah dilakukan, dapat disimpulkan bahwa pembelajaran menggunakan Augmented Reality dapat melatihkan Higher Order Thinking Skills siswa pada materi sistem koordinasi sub pokok bahasan alat indera pada manusia. Hal tersebut dapat terlihat dari adanya peningkatan hasil belajar yang diperoleh siswa yang terlihat dari hasil pretest dan posttest yang menunjukan kategori baik dan sangat baik setelah menggunakan media pembelajaran Augmented Reality sehingga penggunaan media tersebut dapat meningkatkan keterampilan berpikir tingkat tinggi siswa dan berguna untuk kelangsungan proses pembelajaran yang mengacu pada hasil belajar.

\section{UCAPAN TERIMA KASIH}

Peneliti mengucakan terima kasih kapada salah satu SMA di Kabupaten Sukabumi yang telah memfasilitasi peneliti untuk melakukan penelitian ini dan juga penliti ucapkan terima kasih kepada dosen pembimbing yang telah membimbing dalam penyelesaian jurnal penelitian ini.

\section{RUJUKAN}

Anderson, L. W., \& Krathwohl, D. R. (2001). A Taxonomy for Learning, Teaching And Assessing. A Revision of Bloom's Taxonomy Of Educational Objectives. Addison Wesley Longman,Inc.

Arifin, S. Z., Billyardi, R., \& Chandra, W. (2016). Analsisis Keaktifan Siswa melalui Pembelajaran Kooperatif Berbantukan Media Facebook. Utile Jurnal Kependidikan, 2 No 1.

Ariyana, Y., Pudjiastuti, A., Bestary, R., \& Zamromi, Z. (2018). Buku Pegangan Pembelajaran Keterampilan Berpikir Tingkat Tinggi Berbasis Zonasi. Direktorat Jendral Guru Dan Tenaga Kependidikan, 1-87.

Fuchova, M., \& Korenova, L. (2019). Visualisation in Basic Science and Engineering Education of Future Primary School Teachers in Human Biology Education Using Augmented Reality ( Maria Fuchsova, 2019). European Journal of Contemporary Education, 8 (1), 92-102. https://doi.org/10.13187/ejced.2019.1.92

Hartanto, A. (2016). Pengembangan Media Augmented Reality Untuk Mata Pelajaran Biologi Pada Pokok Bahasan Sel. Universitas Pendidikan Indonesia.

Hutchison, A. (2018). Using Virtual Reality to Explore Science and Literacy Concepts. Journal of International Literacy Association, 72(3), 343-353.

Kemendikbud. (2019). Hasil PISA Indonesia 2018: Akses Makin Meluas, Saatnya Tingkatkan Kualitas. https://www.kemdikbud.go.id/main/blog/2019/12/hasil-pisa-indonesia-2018-akses-makin-meluassaatnya-tingkatkan-kualitas

Kouzi, M. E. (2019). Augmented Reality Plant \& Animal Cells : Design and Evaluation of an Educational Augmented Reality Application. Journal of Virtual World Research, 12(3), 1-13.

Nuanmeesri, S. (2018). The Augmented Reality for Teaching Thai Student about the Human Heart. Journal of IJET, 13(06), 203-213.

Ozdamli, F., \& Karagozlu, D. (2018). Presschool Teacher's Opinions on the use of Augmented Reality Application in Presschool Science Education (Fezile Ozdamli, dkk. 2017). Croatian Journal of 
Education, 20 No.1, 43-74. https://doi.org/https://doi.org/10.15516/cje.v20i1.2626

Prasetya Adi, N. (2018). Meningkatkan Higher Order Thinking Skills dan Sikap Terbuka Melalui Media

Pembelajaran Android. JOURNAL OF KOMODO SCIENCE EDUCATION, 01(01), 79-94.

Ryza, P. (2017). Mengenal Assemblr, Platform Berkreasi dengan teknologi AR.

https://dailysocial.id/post/mengenal-assemblr-platform-berkreasi-dengan-teknologi-ar

Sani, R. A. (2019). Pembelajaran HOTS (Edisi Pert). Tri Smart.

Sari, R. R. (2019). Analisis Kemampuan Berpikir Tingkat Tinggi Peserta Didik Kelas XI SMA Pada Materi Sistem Ekskresi. Journal of Bioilmi, 5(2), 91-101.

Shofiyah, N., \& Wulandari, F. E. (2018). Model Problem Based Learning (PBL) dalam melatih Scientific Reasoning Siswa. Jurnal Penelitian Pendidikan IPA, 3(1).

Sugiyono. (2015a). Statistika untuk Penelitian. Alfabeta.

Sugiyono. (2015b). Sugiyono, Metode Penelitian dan Pengembangan Pendekatan Kualitatif, Kuantitatif, dan R\&D , (Bandung: Alfabeta, 2015), 407 1. Metode Penelitian Dan Pengembangan Pendekatan Kualitatif, Kuantitatif, Dan R\&D.

Windyariani, S. (2019). Pembelajaran Berbasis Konteks dan Kreativitas : (Strategi untuk Membelajarkan Sains di Abad 21). Deepublish.

Wulandari, R. (2020). Penggunaan Aplikasi Augmented Reality untuk Memfasilitasi Penguasaan

Konsep dan Keterampilan Berpikir Kreatif Peserta Didik. Jurnal Pendidikan Biologi, 11(02), 59-69. 